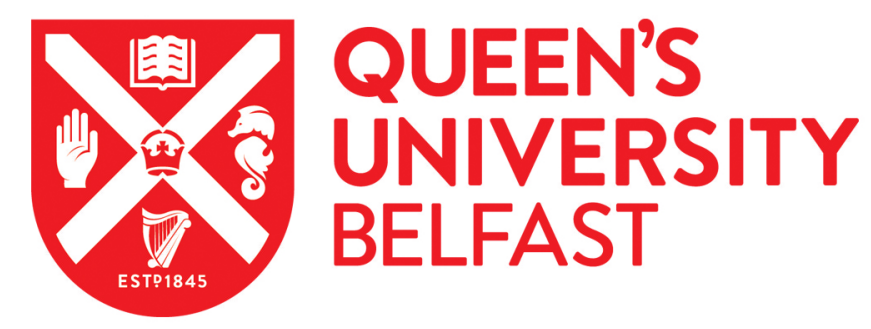

\title{
Evaluation of the role of rank and opg genes in paget's disease of the bone
}

Wuyts, W., Van Wesenbeeck, L., Morales-piga, A., Ralston, S., Hocking, L., Vanhoenacker, F., Westhovens, R., Verbruggen, L., Anderson, D., Hughes, A., \& Van Hull, W. (2001). Evaluation of the role of rank and opg genes in paget's disease of the bone. Bone, 28, 104-107.

\section{Published in:}

Bone

\section{Queen's University Belfast - Research Portal:}

Link to publication record in Queen's University Belfast Research Portal

\section{General rights}

Copyright for the publications made accessible via the Queen's University Belfast Research Portal is retained by the author(s) and / or other copyright owners and it is a condition of accessing these publications that users recognise and abide by the legal requirements associated with these rights.

Take down policy

The Research Portal is Queen's institutional repository that provides access to Queen's research output. Every effort has been made to ensure that content in the Research Portal does not infringe any person's rights, or applicable UK laws. If you discover content in the Research Portal that you believe breaches copyright or violates any law, please contact openaccess@qub.ac.uk. 


\title{
Evaluation of the Role of RANK and OPG Genes in Paget's Disease of Bone
}

\author{
W. WUYTS, ${ }^{1}$ L. VAN WESENBEECK, ${ }^{1}$ A. MORALES-PIGA, ${ }^{2}$ S. RALSTON,${ }^{3}$ L. HOCKING,${ }^{3}$ \\ F. VANHOENACKER,${ }^{4}$ R. WESTHOVENS,${ }^{5}$ L. VERBRUGGEN, ${ }^{6}$ D. ANDERSON, ${ }^{7}$ A. HUGHES ${ }^{8}$ and \\ W. VAN HUL ${ }^{1}$ \\ ${ }^{1}$ Department of Medical Genetics, University of Antwerp, Antwerp, Belgium \\ ${ }^{2}$ Department of Rheumatology, Hospital Ramon y Cajal, Madrid, Spain \\ ${ }^{3}$ Department of Medicine and Therapeutics, University of Aberdeen, Aberdeen, UK \\ ${ }^{4}$ Department of Radiology, University Hospital of Antwerp, Antwerp, Belgium \\ ${ }^{5}$ Department of Rheumatology, University Hospitals KU Leuven, Leuven, Belgium \\ ${ }^{6}$ Department of Rheumatology, University Hospital of Brussels (VUB), Brussels, Belgium \\ ${ }^{7}$ Immunex Corporation, Seattle, WA, USA \\ ${ }^{8}$ Department of Medical Genetics, The Queen's University, Belfast, UK
}

Paget's disease of bone (PDB) is one of the most common bone disorders in the western world. PDB is characterized by focal areas of increased osteoclastic bone resorption and bone formation, which leads to the formation of poorly structured bone. These abnormalities of bone turnover and structure predispose affected individuals to various complications including bone pain, deformity, pathological fracture, and an increased risk of osteosarcoma. One of the main mechanisms of osteoclast formation and activation involves the receptor activator of nuclear factor $-\kappa B$ (RANK)/RANK ligand (RANKL)/osteoprotegerin (OPG) pathway, where binding of RANKL to RANK results in the differentiation of osteoclast precursors. OPG, on the other hand, acts as an inhibitor of osteoclastogenesis by serving as a decoy receptor for RANKL. Recently, mutations in the RANK gene have been shown to cause familial expansile osteolysis, a rare bone disorder showing great similarity to PDB. We performed mutation analysis in the RANK and OPG genes in 28 PDB patients to investigate whether mutations in these genes could be responsible for PDB. Our data suggest that RANK is not directly involved in PDB in our set of patients, as no mutations in the RANK coding region could be identified and allele frequencies of RANK polymorphisms did not differ in PDB patients as compared with the random population. Also, in the OPG gene, we could not detect PDB-causing mutations. However, of the several polymorphisms identified, one $(400+4 \mathrm{C} / \mathrm{T}$ in intron 2$)$, showed a statistically significant increased frequency for the $\mathrm{C}$ allele in PDB patients, suggesting that individuals harboring this allele may be more susceptible for developing PDB. (Bone 28:104-107; 2001) (C) 2001 by Elsevier Science Inc. All rights reserved.

Address for correspondence and reprints: Wim Van Hul, Ph.D., Department Medical Genetics, University of Antwerp, Universiteitsplein 1, 2610 Wilrijk, Belgium. E-mail: vhul@uia.ua.ac.be
Key Words: Receptor activator of nuclear factor $\kappa$ B (RANK); Osteoprotegerin (OPG); Paget's disease of bone; Mutation analysis; Polymorphism; Bone.

\section{Introduction}

Paget's disease of bone (PDB) has an estimated prevalence up to $5 \%$ in the population over the age of 55 years, ${ }^{2,11}$ and is thereby the second leading skeletal disorder affecting the older population of the western world, exceeded only by osteoporosis. The disease involves expedited remodeling, resulting in the formation of structurally abnormal bone, causing an increased risk of fracture, pain, deformity, and osteosarcoma. Both familial and sporadic PDB cases have been described, but it is well recognized that genetic predisposition plays an important role in the development of this disease. ${ }^{9}$ Recent studies have revealed that PDB is a genetically heterogeneous disorder, with a suggested association between PDB and the HLA complex ${ }^{4}$ on chromosome 6 (PDB1), a second locus (PDB2) determined by linkage analysis on chromosome $18 \mathrm{q},{ }^{3,5}$ and at least one other locus elsewhere in the genome. ${ }^{5}$ Interestingly, the PDB2 locus has been mapped on chromosome $18 \mathrm{q},{ }^{3,5}$ in a candidate interval containing the gene for receptor activator of nuclear factor $\kappa$ B (RANK). This gene was initially identified as an important regulator of interactions between $\mathrm{T}$ cells and dendritic cells. ${ }^{1}$ Since its isolation, however, it has been shown that RANK (also known as TNFRSF11A) and its ligand, RANKL, ${ }^{1}$ also called ODF ${ }^{17}$ OPGL,${ }^{8}$ or TRANCE, ${ }^{16}$ are key proteins in bone development and, more specifically, in osteoclastogenesis. Osteotropic factors such as parathyroid hormone (PTH), interleukin-11 (IL11 ), and $1,25(\mathrm{OH})_{2} \mathrm{D}_{3}$ upregulate RANKL in osteoblasts, which is then recognized by RANK expressed on the surface of osteoclast precursors. Binding of RANKL to RANK results in the activation of the NF- $\mathrm{B}$ and c-Jun N-terminal kinase signaling pathways leading to differentiation of osteoclast precursor cells into preosteoclasts, which then further mature into active osteoclasts. The RANK/RANKL interaction is negatively controlled by osteoprotegerin $(\mathrm{OPG})^{13}$ (also known as $\mathrm{OCIF}^{15}$ or TR $1^{13}$ ), a known inhibitor of osteoclastogenesis, which acts as a soluble decoy receptor for RANKL. ${ }^{14}$ 
Table 1. Primers amplifying RANK coding exons

\begin{tabular}{|c|c|c|}
\hline Exon & Sequence $\left(5^{\prime}-3^{\prime}\right)$ & $\mathrm{T}_{\mathrm{m}}\left({ }^{\circ} \mathrm{C}\right)$ \\
\hline \multirow[t]{2}{*}{1} & aaggcggaggagccaggatgc & 63 \\
\hline & tggggtgcggcaaggcaggag & \\
\hline \multirow[t]{2}{*}{2} & aaagagctgtgtggactctctgc & 58 \\
\hline & cacttttgaggggcaatgcaagg & \\
\hline \multirow[t]{2}{*}{3} & gctgttttgctttgtgttgctg & 60 \\
\hline & gtctgaggtttctacacttcc & \\
\hline \multirow[t]{2}{*}{4} & tctgggctggatgttggatagc & 57 \\
\hline & tagcaccetggagctttcttgc & \\
\hline \multirow[t]{2}{*}{5} & ggatgatctctaagtgacctcg & 60 \\
\hline & gaagcctaacccaacagaatcc & \\
\hline \multirow[t]{2}{*}{6} & ggggattcaaatgtccaagaagg & 58 \\
\hline & catgcacgggatgaaataaaggg & \\
\hline \multirow[t]{2}{*}{7} & attctgaggtttgatttaccgg & 57 \\
\hline & ttaagcagatcaccataggcagc & \\
\hline \multirow[t]{2}{*}{8} & aacttgaagtcettatccttgc & 50 \\
\hline & gggtgctcaatatgtgactagg & \\
\hline \multirow[t]{2}{*}{9} & ttccatctgtacttgttatggtgg & 60 \\
\hline & attagcttcctccttcctaaatgg & \\
\hline \multirow[t]{2}{*}{10} & ggttacagtgtggttccetgtg & 63 \\
\hline & cagaggctgcggtgetgecc & \\
\hline
\end{tabular}

Recently, mutations affecting the RANK signal peptide were shown to cause familial expansile osteolysis (FEO), a rare autosomal-dominant bone disorder. ${ }^{7}$ FEO is characterized by the presence of focal lesions of expanding bone, causing serious deformities and increased fracture risk. ${ }^{12}$ There are many similarities between FEO and Paget's disease of Bone, both clinically and histologically, and some investigators have suggested FEO to be a severe form of PDB. In keeping with this hypothesis, one family described by Hughes et al. ${ }^{7}$ showed clinical features of early-onset PDB and FEO, raising the possibility that both disorders are indeed allelic variants caused by different mutations of the same gene. To investigate whether the RANK and OPG genes might be directly involved in Paget's disease of bone, we analyzed both genes for the presence of disease-causing mutations in PDB patients.

\section{Materials and Methods}

\section{Patients}

Twenty-eight PDB patients, 24 sporadic and 4 familial cases, and 50 control individuals of the same ethnic origin were included in this study. The familial PDB cases originated from Spain (two families), the USA (one family), and Barbados (one family). All sporadic PDB patients were of Belgian origin. Diagnoses of all PDB patients were based on radiographs. DNA was isolated from peripheral blood according to standard procedures.

\section{Single-stranded Conformation Polymorphism (SSCP)}

SSCP was performed with intronic primers amplifying all coding exons of the RANK and OPG genes. ${ }^{10}$ All primers are listed in Tables 1 and 2.

The PCR reaction amplification mixture $(20 \mu \mathrm{L})$ contained dNTPs (10 mmol/L each), $10 \mathrm{pmol}$ of two specific primers, $1 \times$ polymerase chain reaction (PCR) buffer, $\left({ }^{32} \mathrm{P}\right)-\alpha \mathrm{dCTP}$, and TaqDNA polymerase. PCR conditions were $5 \mathrm{~min}$ at $96^{\circ} \mathrm{C}, 35$ cycles of $45 \mathrm{sec}$ at $94^{\circ} \mathrm{C}, 45 \mathrm{sec}$ at $\mathrm{Tm}$ and $45 \mathrm{sec}$ at $72^{\circ} \mathrm{C}$, and $10 \mathrm{~min}$ at $72^{\circ} \mathrm{C}$. Tm values for each combination are listed in Tables 1 and 2. For the amplification of exon 1 of the RANK gene, PCR enhancer solution (Gibco) was added to a final concentration of
Table 2. Primers amplifying OPG coding exons

\begin{tabular}{clc}
\hline Exon & sequence $\left(5^{\prime}-3^{\prime}\right)$ & $\mathrm{T}_{\mathrm{m}}\left({ }^{\circ} \mathrm{C}\right)$ \\
\hline 1 & $\begin{array}{l}\text { tegcccagcegcegctcc } \\
\text { gggcaccegtcggctgg } \\
\text { tttcatgctaagatgatgcc } \\
\text { atcctaattaatttgctgcac }\end{array}$ & 60 \\
3 & $\begin{array}{l}\text { aaacgatttgaggagaagg } \\
\text { agagatgatactacaaatcg } \\
\text { aattgttgagtaaatcttctggg } \\
\text { tggtttatgataaataggtgtc } \\
\text { aatgatgtgaacacttatctgg } \\
\text { tgaggaaacagctcaatggc }\end{array}$ & 57 \\
\hline
\end{tabular}

$1 \times$ to improve amplification. Electrophoresis was performed at $500 \mathrm{~V}$ for $16 \mathrm{~h}$ at room temperature.

\section{Sequencing}

PCR amplification products were purified directly from the PCR reaction using a PCR-purification system (Concert Rapid, Clontech) according to the manufacturer's recommendations. Sequencing was performed using Big-Dye Terminator (PerkinElmer) chemistry and sequences were analyzed on an ABI 377 automated sequencer.

\section{Results}

\section{RANK Mutation Analysis}

Previously, the RANK coding region was shown to be comprised within 10 exons $^{7}$ and primer sets amplifying all exons, including intron/exon boundaries, were developed (Table 1). SSCP analyses in 4 familial and 24 sporadic PDB cases showed similar migration patterns for all samples in all exons except for exons 4 and 6.

For further analysis of exon 4, two samples associated with each SSCP pattern were reamplified and sequenced. This revealed that the difference in migration between the various samples was caused by a C421T polymorphism, which results in a H141Y substitution in the RANK protein. As presence of the $421 \mathrm{~T}$ allele generates an $R s a \mathrm{I}$ restriction site, we determined the allele frequencies for this polymorphism in our set of PDB patients and a random population of 50 individuals by reamplification of exon 4 followed by $R s a \mathrm{I}$ restriction digest. No statistically significant difference in distribution was observed in our PDB population compared to the control group with the $\mathrm{C}$ allele present in $47 \%$ of the PDB alleles and in $40 \%$ of the control chromosomes.

Sequence analysis of exon 6 showed a C575T variation resulting in a V192A polymorphism in the RANK protein. A modified PCR primer was developed to create a $C f o$ I restriction site in the presence of the $\mathrm{C}$ allele to determine the allele frequencies for the C575T variation in our PDB population and 50 control individuals. The $\mathrm{C}$ allele was detected in $53 \%$ of the alleles of PDB patients, and in $51 \%$ of the control alleles.

\section{OPG Mutation Analysis}

The genomic organization of the OPG gene has been described previously ${ }^{10}$ and primers amplifying all five coding exons were designed based on sequences available in Genbank AC AB008821 and AC AB008822 (Table 2). SSCP analysis showed a uniform pattern for exon 5 in all patients analyzed, whereas, for 
the remaining four exons, different patterns were observed between the patients. Reamplification and sequence analysis identified several polymorphisms in these four exons.

In exon 1, a G9C polymorphism was identified causing a $\mathrm{K} 3 \mathrm{~N}$ substitution in the OPG protein. The sequence difference did not generate or remove a restriction site, nor could a suitable modified primer be developed. As specific SSCP bands could be assigned to each allele, we performed SSCP analysis on the control population and the results were extrapolated to calculate the allele frequencies. No difference in allele distribution was found between the PDB patients and the control individuals with a frequency of $53 \%$ for the $\mathrm{G}$ allele in the PDB population and $52 \%$ in the controls.

A $400+4 \mathrm{C} / \mathrm{T}$ polymorphism was detected in intron 2 . Both alleles could be distinguished after amplification of exon 2 and digestion with $R s a \mathrm{I}$ for which a restriction site is present in the presence of the $\mathrm{C}$ allele. The $\mathrm{C}$ allele was found to be present on $75 \%$ of the control chromosomes, a frequency that was statistically increased ( $p=0.028$ ) to $89 \%$ in the PDB patients.

Intron 2 contains another polymorphism five bases before the first base of exon 3 where a $\mathrm{C} / \mathrm{T}$ variant was detected. An additional primer set containing a modified primer creating a Pst $\mathrm{I}$ restriction site in the presence of the $\mathrm{T}$ allele was used to determine the allele frequencies. In the control population the $\mathrm{T}$ allele was present on $3.6 \%$ of the chromosomes, whereas PDB patients showed a frequency of $5.5 \%$ for this allele, a difference that did not reach statistical significance $(p=0.520)$.

Exon 4 harbors an $\mathrm{A} 768 \mathrm{G}$ polymorphism, which corresponds to the third codon position of Leucine 256, and therefore does not change the amino acid sequence. By analysis of the SSCP pattern of our control and PDB populations, the A allele was shown to be present in $92 \%$ of the PDB chromosomes and in $85 \%$ of the control chromosomes, a difference that did not reach statistical significance $(p=0.188)$.

\section{Discussion}

Paget's disease of bone is initiated by increased osteoclast mediated resorption characterized by the presence of numerous, multinucleated abnormal osteoclasts. Based on its function in osteoclastogenesis and its genetic localization in the PDB2 candidate region, the RANK gene could be considered a serious candidate for Paget's disease of bone. Moreover, the recent identification of RANK mutations in FEO again raised the question whether both FEO and PDB could be allelic variants caused by different mutations in the same gene. From this perspective it is noteworthy that one of the families harboring a RANK 75dup27 mutation showed a pagetic phenotype with involvement of the axial skeleton, including lesions in the spine, pelvis, and mandible, sites that are normally unaffected in FEO. Therefore, we performed RANK mutation analysis in both sporadic and familial cases of PDB. However, in our set of patients, no RANK mutations could be detected in the coding region. In addition, no association of the $\mathrm{C} 421 \mathrm{~T}(\mathrm{H} 121 \mathrm{Y})$ polymorphism in exon 4 and the C575T (V192A) variation in exon 6 with PDB was detected by comparison of our set of PDB patients with a control group. These data suggest that mutations in the RANK gene are not responsible for the majority of PDB cases. This is not totally surprising, as linkage analysis has also shown that linkage to the locus on $18 \mathrm{q}$ is relatively uncommon in $\mathrm{PDB}^{6}$ and that PDB2 thus probably represents only a minor locus.

The genetic heterogeneity implies that mutations in genes other than the RANK gene must be responsible for the majority of PDB cases. Based on its function as a negative regulator of RANK-RANKL binding, OPG represents a serious candidate gene for PDB. However, we could not detect any disease-causing mutation in the OPG gene in our set of PDB patients. This suggests that mutations in the OPG coding region are not the major cause of PDB. Interestingly however, of the several polymorphisms identified in our study, the $400+4 \mathrm{C} / \mathrm{T}$ variation showed a different distribution in PDB patients compared to the general population. It appears that the presence of a cytosine at this position was seen more frequently in PDB patients, suggesting that individuals harboring this allele may be more susceptible to develop PDB. From this perspective, it is of interest to note that, although this sequence variation represents an intronic polymorphism, it is close to the splice junction of exon 3 . Although highly speculative, one could hypothesize that the presence of either allele might have some effect on the splicing efficiency of this exon. Further analysis must reveal whether this is indeed the case and whether the association of the $400+4 \mathrm{C}$ allele with PDB is of any clinical significance. Therefore, further evaluation of the allele frequencies in a larger set of PDB patients is under way. Alternatively, the observed results could reflect the presence of another, proximal polymorphism associated with predisposition to PDB. In this regard, it must be kept in mind that our analysis does not exclude the presence of sequence variations in the promotor region or possible regulatory sequences up- or downstream from the analyzed OPG and RANK genes, which may affect the expression of these genes. Therefore, a search for polymorphisms in these regions may be worthwhile.

In conclusion, we have demonstrated that the RANK and OPG genes, coding for key players in osteoclastogenesis, do not harbor mutations in their coding sequences in the large set of PDB patients analyzed, but a possible positive association of the $400+4 \mathrm{C}$ allele in intron 2 of the OPG gene with PDB warrants further investigation.

Acknowledgments: W.W. is a postdoctoral researcher of the Fund for Scientific Research, Flanders (FWO), and L.H. was supported by a grant from the National Association for Relief of Paget's Disease (UK). This study was also supported by research grants to W.V.H. from the FWO; a grant from the Arthritis Research Campaign (UK) to S.H.R., W.V.H., and A.M.P.; and grants from the Wellcome Trust, and the Arthritis Research Campaign to S.H.R.

\section{References}

1. Anderson, D. M., Maraskovsky, E., Billingsley, W. L., Dougall, W. C. Tometsko, M. E., Roux, E. R., Teepe, M. C., DuBose, R. F., Cosman, D., and Galibert, L. A homologue of the TNF receptor and its ligand enhance T-cell growth and dendritic-cell function. Nature 390:175-179; 1997.

2. Barker, D. J. P. The epidemiology of Paget's disease of bone. Br Med Bull 40:396-400; 1984

3. Cody, J. D., Singer, F. R., Roodman, G. D., Otterund, B., Lewis, T. B., Leppert, M., and Leach, R. J. Genetic linkage of Paget disease of the bone to chromosome 18q. Am J Hum Genet 61:1117-1122; 1997.

4. Fotino, M., Haymovits, A., and Falk, C. T. Evidence for linkage between HLA and Paget's disease. Transplant Proc 9:1867-1868; 1977.

5. Haslam, S. I., Van Hul, W., Morales-Piga, A., Balemans, W., San-Millan, J. L., Nakatsuka, K., Willems, P., Haites, N. E., and Ralston, S. H. Paget's disease of bone: Evidence for a susceptibility locus on chromosome $18 \mathrm{q}$ and for genetic heterogeneity. J Bone Miner Res 13:911-917; 1998

6. Hocking, L., Slee, F., Haslam, S. I., Cundy, T., Nicholson, G., Van, H. W., and Ralston, S. H. Familial Paget's disease of bone: Patterns of inheritance and frequency of linkage to chromosome 18q. Bone 26:577-580; 2000.

7. Hughes, A. E., Ralston, S. H., Marken, J., Bell, C., MacPherson, H., Wallace, R. G., Van, H. W., Whyte, M. P., Nakatsuka, K., Hovy, L., and Anderson, D. M. Mutations in TNFRSF11A, affecting the signal peptide of RANK, cause familial expansile osteolysis. Nature Genet 24:45-48; 2000.

8. Lacey, D. L., Timms, E., Tan, H. L., Kelley, M. J., Dunstan, C. R., Burgess, T., Elliott, R., Colombero, A., Elliott, G., Scully, S., Hsu, H., Sullivan, J., Hawkins, N., Davy, E., Capparelli, C., Eli, A., Qian, Y. X., Kaufman, S., 
Sarosi, I., Shalhoub, V., Senaldi, G., Guo, J., Delaney, J., and Boyle, W. J. Osteoprotegerin ligand is a cytokine that regulates osteoclast differentiation and activation. Cell 93:165-176; 1998.

9. Morales-Piga, A. A., Rey-Rey, J. S., Corres-Gonzalez, J., Garcia-Sagredo, J. M., and Lopez-Abente, G. Frequency and characteristics of familial aggregation of Paget's disease of bone. J Bone Miner Res 10:663-670; 1995.

10. Morinaga, T., Nakagawa, N., Yasuda, H., Tsuda, E., and Higashio, K. Cloning and characterization of the gene encoding human osteoprotegerin/osteoclastogenesis-inhibitory factor. Eur J Biochem 254:685-691; 1998.

11. Ooi, C. G. and Fraser, W. D. Paget's disease of bone. Postgrad Med J 73:69-74; 1997.

12. Osterberg, P. H., Wallace, R. G., Adams, D. A., Crone, R. S., Dickson, G. R., Kanis, J. A., Mollan, R. A., Nevin, N. C., Sloan, J., and Toner, P. G. Familial expansile osteolysis. A new dysplasia. J Bone Joint Surg [Br] 70:255-260; 1988.

13. Simonet, W. S., Lacey, D. L., Dunstan, C. R., Kelley, M., Chang, M. S., Luthy, R., Nguyen, H. Q., Wooden, S., Bennett, L., Boone, T., Shimamoto, G., DeRose, M., Elliott, R., Colombero, A., Tan, H. L., Trail, G., Sullivan, J., Davy, E., Bucay, N., Renshaw-Gegg, L., Hughes, T. M., Hill, D., Pattison, W., Campbell, P., and Boyle, W. J. Osteoprotegerin: A novel secreted protein involved in the regulation of bone density. Cell 89:309-319; 1997.

14. Suda, T., Takahashi, N., Udagawa, N., Jimi, E., Gillespie, M., and Martin, J.
Mutation analysis of RANK and OPG in PDB

Modulation of osteoclast differentiation and function by the new members of the tumor necrosis factor receptor and ligand families. Endocrine Rev 20:345357; 1999.

15. Tsuda, E., Goto, M., Mochizuki, S., Yano, K., Kobayashi, F., Morinaga, T., and Higashio, K. Isolation of a novel cytokine from human fibroblasts that specifically inhibits osteoclastogenesis. Biochem Biophys Res Commun 234:137$142 ; 1997$.

16. Wong, B. R., Josien, R., Lee, S. Y., Sauter, B., Li, H. L., Steinman, R. M. and Choi, Y. TRANCE (tumor necrosis factor [TNF]-related activation-induced cytokine), a new TNF family member predominantly expressed in T cells, is a dendritic cell-specific survival factor. J Exp Med 186:2075-2080; 1997.

17. Yasuda, H., Shima, N., Nakagawa, N., Yamaguchi, K., Kinosaki, M., Mochizuki, S., Tomoyasu, A., Yano, K., Goto, M., Murakami, A., Tsuda, E., Morinaga, T., Higashio, K., Udagawa, N., Takahashi, N., and Suda, T. Osteoclast differentiation factor is a ligand for osteoprotegerin/osteoclastogenesis-inhibitory factor and is identical to TRANCE/RANKL. Proc Natl Acad Sci USA 95:3597-3602; 1998.
Date Received: July 20, 2000

Date Accepted: September 12, 2000 